\title{
Impact of a Growing Population in Agricultural Resource Management: Exploring the Global Situation with a Micro-level Example
}

\author{
A. H. M. Zehadul Karim ${ }^{1}$ \\ ${ }^{1}$ Department of Sociology and Anthropology, International Islamic University Malaysia, Gombak, Kuala \\ Lumpur, Malaysia \\ Correspondence: A. H. M. Zehadul Karim, Department of Sociology and Anthropology, International Islamic \\ University Malaysia, Gombak 53100, Kuala Lumpur, Malaysia. Tel: 60-16-390-7940. E-mail: \\ ahmzkarim@yahoo.com
}

Received: July 2, 2013 Accepted: August 21, 2013 Online Published: October 29, 2013

doi:10.5539/ass.v9n15p14 URL: http://dx.doi.org/ass.v9n15p14

\begin{abstract}
A decade ago, David Pimentel and his associates (1998) reported to us that at least ten million hectares of arable land were being eroded and also abandoned throughout the world every year and consequently to compensate such a loss, a huge amount of replacement is claimed from forests and other sources for agriculture and human settlement. In the meantime, world population exceeded 6 billion in the year 1999, and the projected data indicate that it is going to be almost 9 billion within the next 40 years. For that reason, the demographers and environmentalists have highlighted that the main challenge for environmental management throughout the world today is to determine our planet's capacity to sustain such a huge amount of burgeoning human population. The paper thus assesses specifically the impact of growing population on agricultural resources around the world, creating depressing pressure on sustainable environmental management. To exemplify such a trend of agricultural land use, the paper incorporates a detailed example from an ethnographic case study on indigenous land-use practices and the experiences associated with modern cultivation for adapting to adverse situations caused by severe impact of a growing population in the agricultural sector in rural Bangladesh.
\end{abstract}

Keywords: growing population, agricultural resource management, impact in global situation

\section{Introduction and Contextualizing the Issue}

In the last few decades, there has been great concern over the issue of natural resource management in the global context. People are very much aware that the supply of various non-renewable natural resources on this planet is shrinking rapidly due to over-exhaustion and enhancement of resource appropriation. There has been rapid transformation of the world's natural landscape to agriculture, and it is learned that such use of natural resources will soon exceed its carrying capacity by causing an irreversible damage to its natural ecosystem. While land use practices often vary greatly across the world, their ultimate purpose usually remains the same which is to extract the natural resources for instant social needs, knowing clearly the severe impact of it on the environment. In the meantime, the world population has increased from 3 billion in 1959 to 6 billion in 1999, which took only 40 years for it to double. The US Census Bureau of the International Data Base also projected and mentioned that this number will be 9 billion in the year 2044, an increase of 50\% within a span of 45 years (US Census Bureau, 2010). Accordingly, the demographers and environmentalists have posed a concern; the main challenge for the global environment is to determine our planet's capacity to sustain such a huge number of growing populations. In this context, the carrying capacity (Note 1) of the planet may further be measured by calculating the per capita requirement of food and nutrition subsistence. To provide adequate food subsistence to the people living with diverse diet will require at least 0.5 hectare of arable land per person (Lal \& Steward, 1990), and at this time, we have only 0.27 hectare per capita land available to us, which will drastically be reduced to 0.14 hectare per person within the next 40 years due to loss of land caused by population pressure (Pimentel, 1993; Pimentel et al., 1994; Pimentel et al., 1995; Pimentel, 1997). In his book titled 'World Soil Erosion and Conservation' published in the year 1993, David Pimentel mentioned that per capita shortage in the availability of land has remained the major reason for severe food shortage and malnutrition in many parts of the world. The environmental depression is further intensified due to soil erosion in agricultural areas where 75 billion of metric 
tons of soil are demolished from the fields through wind and water, mostly affecting the cultivatable land (Myers, 1993). Furthermore, it is documented that deforestation and desertification have been occurring in the last two decades causing the human beings to be more vulnerable to shortages of land (Skole \& Tucker, 1997). In the process of deforestation and desertification, more forest areas are converted for required farming activities (Note 2).

Based on the foregoing contextual introduction, the main purpose of this paper is to assess specifically the impact of growing population on available agricultural resources around the world which creates pressure on indigenous and sustainable agricultural management. Purposively therefore, the paper has four-fold collectives to relate demography with the available natural resources. At the initial point, the paper provides an outline of quantitative documentation showing a linear increase of the world's population in recent times. While the population grows at an unexpectedly speedy geometrical configuration as theoretized by Thomas Robert Malthus (1798), it is quite certain that this huge number of population will require food, water, and settlement which will force the world to place unexpected pressure on natural resources and land (Note 3). A comprehensive research on the world's major land use practices in recent times indicates that at least one-third of the world's land surface is now used for agriculture and millions of acres of land every year are converted to cultivation (Foley, 2005).

From this perspective, the paper will briefly provide information in regard to loss of natural resources annually for farming purposes. To exemplify such a trend in agricultural land use, the paper in its later section will show the direct impact of population growth on a farming community. More indicatively, the author depicts clearly the transitional transformation of the indigenous technique of farming to modern cultivation, requiring heavy demand on irrigation and chemical fertilizer which subsequently degrade the original fertile land and environment at the local level; such is the demographic impact on agricultural resource management. The paper finally concludes with a very modest caution for all inhabitants of this planet, saying that a judicious use of the environment is fully dependent on the honest formulation of accurate policies to keep population below replacement level. This is very much an essential and strategic requirement in our indigenous way of survival and resource management.

From the methodological point of view, the paper has adopted a conjunctive technique of triangulation where the secondary sources of data from global perspective have conceptualized an analytic-descriptive framework for explaining the world's demographic situation, contextualizing its impact on environmental resource management. In consonance with the above dimension, the paper has incorporated an ethnographic documentation at the micro-level, showing the situation at the village level. As a matter of fact, this is an important test on the effectiveness and accuracy of what has been stated at the macro perspective in the global context and an ethnographic brief in this context is proving our statement at the field level.

\section{Population Growth around the World: Its Equation and Impact Assessment}

Since the beginning of human history through the early 1800 s, the global population had been increasing more or less at a consistent rate and as such, it did not pose any serious threat for the people around the world until that time. The overall statistics on world population exhibit that it remained at 1 billion until 1830, and it took 100 years to double the population to 2 billion in the year 1930. But subsequently, within a range of 30 years later in 1960 , the cumulative growth of population stood at 3 billion worldwide. It took only another 15 years in 1975 to increase the total population of the world to 4 billion. To explain more analytically, the causative factor for a lower number of population growth prior to 1930 was not for its lower birth, but because of the high rate of mortality due to some severe and uncontrollable epidemics which caused a huge number of world population to perish at that time ${ }^{4}$. The mortality rate in those days further increased due to conditions like famines, accidents, etc., which reduced human population even though there was high fertility. It is clear from the above statistics that within a stipulated period of only 45 years from 1930 to 1975 the population of the world had simply doubled. In this continuous process, twelve years later in 1987, the population of the world reached 5 billion. In the year 1999, it became 6 billion which further increased to 6.8 billion in the year 2009 (Population Reference Bureau, 2009). World population is expected to grow to 8.9 billion in 2050, and much of the demographic change up to this period will occur in the less developed nations. Although at present the population growth rate is 76 million a year, it does not seem to be appreciating much. 
Table 1. Global population situation

\begin{tabular}{llll}
\hline Year & Population (in Billion) & Total Fertility Rate & \\
\hline 1830 & 1 & 1969 & 6 \\
1901 & 1.4 & 1999 & 3 \\
1930 & 2 & Population Growth Rate & \\
1960 & 3 & 1969 & 2.4 \\
1975 & 4 & 1999 & 1.9 \\
1987 & 5 & & \\
1999 & 6 & World population projected for 2050: 9.1 billion \\
\hline
\end{tabular}

Sources: Prema Ramachardaran et al.; 2008; UNDP 2009. Rearranged and Modified

Although the overall population growth rate throughout the world had decreased considerably during the later part of the last century, the population growth rate in general remained consistently high in many poor and underdeveloped countries. During 1960, the population growth rate throughout the world peaked at $2.4 \%$ per year which was later reduced to $1.8 \%$ during 1999 meaning there is an increase of 87 million people every year. Extrapolating on such trend of lower fertility rate, UNDP's projected data clearly indicate that the world population will reach 9.1 billion by 2050 (Wright, 2008; UNDP, 2009). Rising population has already been a problem for many poor and developing nations of the world. For instance, the population in India which is approximately 1.8 billion inhabits an area of 3,287,240 sq. km. Its current growth rate is $1.9 \%$ per year which will double in the next 37 years (PRB, 1995; as quoted in Pimentel, 1998). Similarly, China has 1.27 billion people with a growth rate of $1.1 \%$ which is the optimum desirable rate of the percent size (Qu \& $\mathrm{Li}, 1992)$. Despite the government's effort to reduce the growth rate by allowing only one child per couple, the population of China has continued to increase every year. One of the poorest countries of the world, Bangladesh has about 153 million people living in a surface area of $147570 \mathrm{sq} . \mathrm{km}$. In 1930, its total population was only 35.5 million which has now increased to more than four times to make it 153.50 million in 2008; Bangladesh now faces a daunting challenge to feed its population where at least half of them are living in food based poverty level (Cuffaro, 1997; Karim, 2011).

The total population of China, India, Bangladesh, Pakistan, Nigeria, Indonesia, Brazil and Ethiopia account for almost half of the total world population (UNDP, 2008). A few Asian (e.g. Malaysia) and Middle Eastern countries (e.g. Iraq, Iran, Saudi Arabia \& Turkey) do not have any demographic problem in regard to their population size until now, as they possess sufficient land and natural resources which provide them with enormous economic prosperity. Yet it is suspected that they might face problems due to an increase in population in the near future. As demographers, we may need to caution them about their future.

\section{Population Pressure on Land and Agricultural Resources: Global Context}

Population increase in many parts of the world has consequential effect on agricultural resource because an excessive growth of population can drastically minimize agricultural land throughout the world. It is reported that agricultural land which extracts food and cereals contain only $12 \%$ of the total land area of the planet which does not seem to be sufficient in terms of covering the subsistence of such a huge incumbent population. Of the remaining total $24 \%$ are arid grass land which is used for pasturing and grazing purposes, and another $30 \%$ is covered by forest necessary to protect the environment from greenhouse effect and other climatological imbalances. The remaining 34 per cent of the total land of the planet is fully unusable for any crop production as they are stony, too steepy or are exposed to extremely dry, cold and wet atmospheric conditions (Buringh, 1989). These lands are simply geologically infertile, unusable for pastures as grass land, and climatically unsuitable for crop production (Pimentel, 1989).

Thus, it becomes logical that when population grows at an unlimited rate, it obviously puts pressure on our marginally available $12 \%$ of useable agricultural land, the supply of which is also shrinking day by day (Note 4 ). An extreme growth of population also squeezes the per capita availability of cultivable land. Based on evidence, it is calculated that at present, we require 0.5 hectare per capita crop land as a minimal requirement to sustain a proper diet and nutrition. But due to continuous population growth and also rapid land degradation, the availability of per capita land is reduced to an extreme point day by day (Leach, 1995). In many Third World countries, it is far below the global average, putting people under serious food shortage and effectual causation 
of poverty and hunger. An example can be found in Honduras where John Pender (1999) formulated a hypothesis on the impact of rural population on productivity, poverty and natural resource management. Pender's argument seems to be relevant for this research which also has shown the implications of demographic pressure on the farm-based agrarian households in rural Bangladesh. There is however, another research conducted by D.G. Satihal, L.D. Vaikunthe and P.K. Bhargava (n. d.) which documents those rapid demographic and agricultural changes in various parts of Karanataka District for the last few decades. The paper has however, shown that there is a large variation in the general land utilization pattern and availability of cultivated land in different parts of the district. Bivariate analysis of data however, suggests that agricultural growth in all cropped areas of the district largely lag behind population growth, except in a few areas where there are higher growths of food crops.

We know that land and its terrestrial environment is essentially an important natural resource which provides 99\% of humans' food requirement (Pimentel \& Pimentel, 1996). Thus logically, it is quite likely that when this land is under serious threat due to population growth, farmers need to use the same land repeatedly through intensive multi-cropping production. When farmers go for intensive cultivation, they have to utilize mechanized farming and make an abrupt shift from their traditional indigenous farming system. The introduction of mechanized farming provides a sharp increase of crop production which is essential to support a growing population. Traditional subsistence farming in Asia and Africa in the past involved the rotating cultivation or mono-cropping, keeping the land fallow for some time, which as a matter of fact allowed the land to be revitalized and regain its nutrients. But with the increase of population, people put continuous pressure on land, without allowing them any time off. The resulting consequence is the deterioration of the soil which keeps the land fully dependent on chemical fertilizer and uncontrolled irrigation. Therefore, peasants moving towards mechanized farming no longer depend on seasonal rain and also at the same time, are totally dislodged from indigenous farming mechanisms. Due to mechanized farming, crop production increases, yet a complimentary notion develops when people usually care less about reducing the population.

\section{Demographic Impact on Agricultural Land Use: A Micro-Level Example from an Ethnographic Research}

This part of the research has its ethnographic documentation on two villages in Bangladesh. Dhonjoypara and Gopalhati, are both agricultural communities located in the same physiographic and environmental setting. They belong to Puthia union (Note 5) of Rajshahi District in the north-western part of Bangladesh. Physiographically, Puthia and these villages lie on the outer margin of the riparian tract which is about eight miles in land from the left bank of the Padma River. It lies in the southern low-lying bed or depressed marshy area (Siddique, 1976). It is situated over $25^{0} 22$ north latitude and $88^{0} 50$ east longitude (Hossain et al., n. d.). The mean temperature for Puthia and these study villages increases from $63^{\circ} \mathrm{F}$ in January to more than $85^{\circ} \mathrm{F}$ in the summer months. Of the yearly rainfall of about 56 inches, no less than 50 inches fall in the rainy season. Compared to other parts of the country, the rainfall of Puthia villages is far less, which speaks of the necessity for irrigation of its land.

On the basis of surface level, there are three types of land in Puthia (Note 6): (1) Daira or also known as bhiti land, meaning land for homestead or the elevated land above flood-level; (2) Mathan or the flat fields of intermediate level which are partially flooded during the rainy season; and (3) Layal or the low-lying land which is completely flooded during the rainy season. These diverse soils of the villages provide them with diversified cropping pattern (Note 7).

\section{Settlement Trends: Agricultural Land Use and the Population Dynamics in the Villages}

We will examine the settlement trend, land use pattern and the population dynamics in Dhononjoypara and Gopalhati to provide data for the micro-level investigation. Information about village settlement prior to 1850 is not available. According to the first Village Revenue Survey of 1850, Dhononjoypara contained 205 acres of land, while Gopalhati had 393 acres of land in its mouza. The Village Revenue Survey of 1850 indicated that mouza Dhononjoypara at that time had only five households occupying a total of nine acres for homesteads. The amount of cultivable land in Dhononjoypara was 190 acres and the remaining 6 acres were waste and uncultivated. On the other hand, Gopalhati had 14 households having 25 acres for homesteads; the amount of cultivable land was 368 acres. 
Table 2. Land-use pattern for villages Dhononjoypara and Gopalhati villages since 1850 (in acres)

\begin{tabular}{|c|c|c|c|c|c|c|c|}
\hline \multicolumn{4}{|c|}{ Dhononjoypara } & \multicolumn{4}{|c|}{ Gopalhati } \\
\hline $\begin{array}{l}\text { Census } \\
\text { Year }\end{array}$ & $\begin{array}{l}\text { Land Used for } \\
\text { Settlement }\end{array}$ & $\begin{array}{l}\text { Land Used } \\
\text { for } \\
\text { Cultivation }\end{array}$ & $\begin{array}{l}\text { Waste and } \\
\text { Uncultivable } \\
\text { land }\end{array}$ & Total & $\begin{array}{l}\text { Land Used } \\
\text { for } \\
\text { Settlement }\end{array}$ & $\begin{array}{l}\text { Land Used for } \\
\text { Cultivation }\end{array}$ & Total \\
\hline 1850 & 9 & 190 & 6 & 205 & 25 & 369 & 393 \\
\hline 1968 & 58 & 152 & - & 210 & 99 & 293 & 392 \\
\hline 1974 & $\begin{array}{l}\text { No } \\
\text { Information }\end{array}$ & $\begin{array}{l}\text { No } \\
\text { Information }\end{array}$ & $\begin{array}{l}\text { No } \\
\text { Information }\end{array}$ & 210 & $\begin{array}{l}\text { No } \\
\text { Information }\end{array}$ & $\begin{array}{l}\text { No } \\
\text { Information }\end{array}$ & 399 \\
\hline
\end{tabular}

The Census Reports of 1951 and 1961 provided information on population, household and literacy but did not give any information on settlement pattern, thereby making it impossible to analyze in detail the changes over time. However, the Revisional Settlement Survey of 1968 which came out in 1978 filled the vacuum in this regard, and the Census Report of 1974 provided gross data on the total amount of land available in each village. According to the Revisional Settlement Survey (1968), mouza Dhononjoypara had 210 acres of total land of which 152 acres were cultivated. In Gopalhati, there were 392 acres of total land, of which 99 acres had been used as settlement and the remaining 293 acres were agricultural land. It may be inferred from the Revisional Settlement data that there has been a tremendous increase of land for settlement in both villages since 1850 . The reason is obviously the increase in population.

In addition to natural growth of the local population, in-migration to this low density populated area from the high density districts of eastern Bangladesh further augmented the population growth. Khan's (1977) study of migration in Puthia villages can be cited as an example to support this statement. The Census Report of 1974 estimated 210 acres of total land for Dhononjoypara, and 399 acres for Gopalhati. This estimate for Dhononjoypara is quite consistent with the Revisional Settlement data, but for Gopalhati, the figure projects a slight variation in the estimation, the reason remains unknown to us (Table 3).

According to the village census that was administered during the field work (August 1984 to August 1985), there were 660 people in Dhononjoypara, of which 591 (89.55\%) were Muslims and the remaining 69 (10.45\%) were from a tribal community named the Santal. In Gopalhati, out of a total 1207 people, Muslims constituted 1142 (94.61\%) while $65(5.39 \%)$ were the Hindus. The average household sizes for Dhononjoypara and Gopalhati were 6.28 and 6.18 persons respectively which were slightly higher than the national average. Data gathered from my revisitation of the villages indicate that there has been a sharp increase in the population in recent years and the statistics show that within a span of 25 years, the increase rate of population growth in both villages has gone up to $80 \%$ and it is suspected that it will take only $4-5$ years to double the percentages (Table 3 ).

To have a clear picture of population growth in Dhononjoypara and Gopalhati, a demographic view of the villages since 1951 to present time is shown in Table 3. To enquire about the population transition of the villages for the past century it is necessary to know the population dynamics of Puthia Union and Puthia Upazila as a whole. Census recording in the sub-continent of Bangladesh-India and Pakistan began as late as 1872. But there is no information on population at the village level, nor does the Village Census of 1901 dealt specifically with village statistics. It was simply a camouflage in the name of Village Census. In fact, population statistics at the village level only came into existence in 1951.

Table 3. Demographic data for villages Dhononjoypara and Gopalhati (selected years 1951-2011)

\begin{tabular}{llllllllllll}
\hline \multicolumn{3}{l}{ Village Dhononjoypara } & \multicolumn{1}{c}{ Village Gopalhati } \\
\hline Year & $\begin{array}{l}\text { Numbe } \\
\text { r of HH }\end{array}$ & $\begin{array}{l}\text { Total } \\
\text { Population }\end{array}$ & Male & Female & Literacy & Year & $\begin{array}{l}\text { Number } \\
\text { of HH }\end{array}$ & $\begin{array}{l}\text { Total } \\
\text { Population }\end{array}$ & Male & Female & Literacy \\
1951 & No data & 350 & $\begin{array}{l}\text { No } \\
\text { data }\end{array}$ & $\begin{array}{l}\text { No } \\
\text { data }\end{array}$ & No data & 90 & 380 & $\begin{array}{l}\text { No } \\
\text { data }\end{array}$ & $\begin{array}{l}\text { No data } \\
\text { data }\end{array}$ & No data \\
1961 & 72 & 371 & 195 & 176 & 15.36 & 93 & 513 & 264 & 249 & 11.11 \\
1974 & 62 & 348 & 164 & 84 & 2069 & 151 & 959 & 478 & 481 & 11.57 \\
1985 & 105 & 660 & 345 & 316 & 23.60 & 196 & 1207 & 631 & 576 & 14.17 \\
2011 & 199 & 915 & 471 & 444 & 43.60 & 299 & 1964 & 997 & 967 & 44.50 \\
\hline
\end{tabular}

Source: Census reports 1957, 1961, 1974 and field study 1984-85; field reports, 2011. 
The reported census of 1872 and 1901 produced data on the thana (i.e., present upazila) level which indicate that there has been decades of declining population in Puthia Upazila. The Bengal District Gazetters-Rajshahi-1916 (O'Malley, 1916) indicate that the population of Puthia and adjoining Upazilas (i.e., Bagmara, Mohanpur, Paba \& Charghat) declined tremendously between 1872 and 1891 due to prevalence of malaria, smallpox, and cholera together with water-hyacinth which blocked the water channels. This caused a $15.01 \%$ decrease of population growth (1976, p.48). Through 1901, Puthia and the adjoining upazilas sustained a loss of population by a decrease of $12.08 \%$ (O’Malley, 1916). Many people died in this swampy water-logged area and others migrated to the comparatively healthier and more prosperous areas (Naogaon \& Panchupur, n. d.) of Rajshahi Region (O'Malley, 1916). Nelson (1923) reported that the population of Puthia decreased by 44\% between 1872 to 1912. This declining population trend for Puthia continued until 1951 due to a large emigration of the Hindus to India during and after 1947 (Hossain et al., n. d.). From 1951 onwards, the population had again increased in Puthia Union, as it had for Dhononjoypara and Gopalhati. The increase of population for Puthia Union between 1951 and 1960 is $32.2 \%$ (Hossain et al., n. d.). This growth rate has been mostly due to increasing birth rates. Side by side with the population growth, we find that there had occurred a tremendous loss of the agricultural land in the villages of Dhononjoypara and Gopalhati.

\section{Findings and Discussions}

Based on our foregoing discussion, it is discernible that since the beginning of human history, global population had increased tremendously at a continued process putting the people on the earth in enormous problems and economic hardship. It has been evidenced that when the world population was 1 billion until 1830, it took only 100 years to double the number to be 2 billion in 1930. We found that within a span of 45 years, this number has reached to another double to make it 4 billion in 1975. There was an addition of another two billion people by the end of the Twentieth century to enhance world population 6 billion in 1999. Thus it has been observed that with the passing of time in every sequence, doubling time for population increase is becoming lesser and lesser. Such increase of population requires more and more land for settlement and habitation having a direct impact on natural resources. It has been calculated that overpopulation is the prime reason for reducing per capita availability of land. To substantiate this statement, the paper has incorporated an ethnographic documentation of two villages from Bangladesh where it has been evidenced that demographic pressure has resulted in the transformation of agricultural land. Based on the data, it has been found that this loss of land in the villages Dhononjoypara was $18 \%$ and for Gopalhati, it was $19 \%$. During my field-visits in early 2012, the villagers reported to me that almost half of the agricultural land in both the villages has been taken for settlement until recently. It is thus indicative that population increase puts heavy pressure on cropland when the people in the rural areas have been compelled to divert their farming land for purpose of settlement and habitation.

\section{Conclusion and Recommendations}

Rapid population growth has been identified as the single most important factor for environmental degradation, which puts people in extreme poverty and also deteriorates human life in many nations of the world. It causes tremendous transformation of the world's natural landscape to agriculture, and it has been documented clearly in our discussion that agricultural resource will soon exceed its capacity by making an irreversible damage to the ecosystem of this planet. In my paper, I have documented the gradual increment rate of population growth in the global context, and also at the same time, I have provided ethnographic documentation of the pattern of such growth at the village level. It has been argued by a few scholars (e.g., Buchholz, 1993; Karim, 2010) that the future of food security and land protection entirely depends on the control of and restriction on births than emphasis on unusual use of chemical fertilizer to boost agricultural production. There is argument that it is more humane and ethical to implement family planning programme to keep the population at the lowest level than allow people to be victims of starvation. To allow the increase in population is nothing but to cause starvation, health problems, increasing unemployment and finally the destruction of the environment. This is particularly true for some Third World countries like India, Pakistan, Bangladesh, Ethiopia, Indonesia and Nigeria where there is rapid increase of population among the lower-income and poorer sections. It is assumed that family planning programme do not work properly in these countries at the rural level. Government $s$ and the NGOs in many of these countries try to popularize family planning programme among the wealthy, rich and educated segments of society who are nevertheless are quite aware of the situation (Karim, 2010). We must remember that when population increases effectually much cropland is taken for urban and rural habitation. In order to feed many mouths, farmers have to use excessive fertilizers and pesticides which eventually destroy the fertility of the soil and also at the same time, negatively affect human health. It has been proven from the ethnographic examples given in this paper that there has been a tremendous shrinking of agricultural land in the two villages of Bangladesh within the span of one hundred years. This is particularly true for Bangladesh as well as for other 
developing nations like India, China and Indonesia, which have all the potential of development but often lag behind because of their demographic pressure and man-land low achievement (see Kumar, 2000 for details on this).

Based on the above contention, however, I formulate in my conclusive statement a very simple formula below for the peasants around the world in regard to their agricultural land-use pattern throughout the years, stating that, we must find out a mechanism to deal with such a huge number of growing population around the world at this critical situation. The first suggestion is that each and every nation around the world should formulate their own policies immediately with a target to bring the population growth at a replacement level, and simultaneously they should invent some techniques to solve the food crisis throughout the world.

\section{References}

Ahmed, A., \& Ryosuki, S. (2000). Climate Change and agricultural food production at Bangladesh: an impact assessment using GIS-based Biophysical Simulation model. A paper published by the Center of Spatial Information Science in Tokyo, Japan.

Ahmed, I. (1979). Employment in Bangladesh: Problems and Prospects. A paper presented at the Fourth Economics Association Conference. Dhaka, January 6.

Buchholz, R. A. (1993). Principles of Environmental Management. New Jersey: Prentice-Hall.

Buringh, P. (1989). Availability of agriculture land for crop and livestock Production. In D. Pimentel \& C. W. Hall (Eds.), Food and Natural Resources (pp. 69-83). San Diego: Academic Press.

Cuffaro, N. (1997). Population Growth and Agriculture in Poor Countries: A Review of Theoretical Issues and Empirical Evidences. World Development, 25(7), 1151-1163. http://dx.doi.org/10.1016/S0305-750X(97)00025-9

Foley, J. A. (2005). World land use seen as Top Environmental issue. Science Daily. Special Bulletin.

Government of Pakistan. (1951). Census of East Pakistan. Karachi: Government Press.

Government of the People's Republic of Bangladesh. (1974). Village Census (1974). Dhaka: Bureau of Statistics.

Hossain et al. (n. d.). The Pattern of a Peasant Economy, Puthia-A Case Study. Rajshahi: Socio-Economic Survey Project, Rajshahi University.

Jaya, K., \& Stanley, G. (2000). Population and Environment by 2000 AD - A Social Manifesto. The International Journal of Sociology and Social Policy.

Karim, A. H. M. Z. (1990). The Pattern of Rural leadership in an Agrarian Society: A Case Study of the Changing Power Structure in Bangladesh. New Delhi: Northern Book Center.

Karim, A. H. M. Z. (2011). Agro-based Food Production System in Bangladesh: A Socio- Demographic Impact Assessment from Asian Examples. The Social Sciences, 6(6), 473-479.

Khan, S. H. (1977). Beyond the Trap of Traditions. In Migrants and Locals in a Rural Community of Bangladesh. Unpublished M. Phil. Thesis. Institute of Bangladesh Studies, Rajshahi University.

Lal, R. (1989). Land Degradation and its Impact on Food and other Resources. In D. Piementel (Ed.), Food and Natural Resources. San Diego: Academic press.

Leach. (1995). Global Land and Food in the 21st Century. Stockholm: International Institute for Environmental Technology and Management.

Malthus, T. R. (1798). Essay on the Principle of Population. London: Macmillan.

Meyer, B. W., \& Turner, B. L. (1992). Human Population Growth and Global Land-Use/Cover Change. Annual Reviews Ecological Systems, 23, 39-61. http://dx.doi.org/10.1146/annurev.es.23.110192.000351

Myers, N. (1993). Gaia: An Atlas of Planet Management. Garden City: Anchor and Doubleday.

Nelson, W. H. (1923). Final Report on the Survey and Settlement Operation in the District of Rajshahi: 1912-1922. Calcutta: The Bengal Secretariat Book Department.

O’Malley, L. S. S. (1916). Bengal District Gazetteers: Rajshahi. Calcutta: The Bengal secretariat press.

Pender, J. (1999). Rural Population Growth, Agricultural Change and Natural Resource Management in Developing Countries: A Review of Hypotheses and some evidences from Honduras. EPTD Discussion paper. Washington D.C. International Food Policy Research Institute. 
Piementel et al. (1994). Natural Resources and Optimum Human Population. Population and Environment, 15, 1117-1123. http://dx.doi.org/10.1126/science.267.5201.1117

Piementel et al. (1996). Food Energy and Society. Colorado: University Press of Colorado.

Pimental, D. (1997). Environmental and Economic costs of Soil. In U. Tim (Ed.), Environmental management: readings and case studies. Oxford: Blackwell Publishers.

Pimentel et al. (1995). Environmental and economic cost of soil erosion and conservation benefits. Science, 267, 1117-1123.

Pimentel et al. (1998). 'Impact of a Growing Population on Natural Resource Management: The Challenge for Environmental Management'. In B. Nath (Ed.), Environmental Management in Practice (pp. 6-21). London and New York: Routledge.

Pimentel, D. (1989). Ecological Systems, natural resources, and food supplies. In D. Pimentel \& C. W. Hall (Eds.), Food and Natural Resources (pp. 1-29). San Diego: Academic Press.

Pimentel, D. (1993). World Soil Erosion and Conservation. Cambridge: Cambridge University Press. http://dx.doi.org/10.1017/CBO9780511735394

Pimentel, D., \& Marcia, P. (2006). Global Environmental Resources versus World Population Growth. Ecological Economics, 59. http://dx.doi.org/10.1016/j.ecolecon.2005.11.034

Qu, G., \& Li, J. (1992). Population and Environment in China. Beijing: China Environmental Science Press (In Chinese), referred in Pimentel (1994).

Ramchandan et al. (2008). Population Growth: Trends, Projections, Challenges and Opportunities.

Sathial, D. G., Vaikunthe, L. D., \& Bhargava, P. K. (Eds.). (n. d.). Population Growth on Agricultural Land Utilization in Karnataka, India. Research Centre. JSS, Institute of Economic Research, Karnataka University Dharwad.

Schneider et al. (2011). Impacts of population growth, economic development, and technical change on global food production and consumption. Agricultural Systems, 104, 204-215. http://dx.doi.org/10.1016/j.agsy.2010.11.003

Siddique, A. (1976). Bangladesh District Gazetter-Rajshahi. Dhaka: Bangladesh Government Press.

Skole, D., \& Comton, T. (1997). Tropical deforestation and Habitat Fragmentation in the Amazon: Satellite Data from 1978 to 1988. In A. O. Lewis \& U. Tim (Eds.), Environmental management: readings and case studies. Oxford: Blackwell publishers.

Timah, E. A., Nji, A., Divine, F. T., Leonard, M. N., \& Irne, B. B. (2008). Demographic pressure and natural $\begin{array}{llll}\text { resources } & \text { Ecological }\end{array}$ http://dx.doi.org/10.1016/j.ecolecon.2007.08.024

UNDP (United Nations Development Program). (2009). Human Development report 2009. New York: Oxford University Press.

United Nations Population Reference Division. (2009). World Population Prospects 2007. Retrieved February 9 , 2009, from http://www.data.un.org

Wright, R. (2008). Environmental Science: Toward a Sustainable Future. NJ: Pearson: Prentice Hall.

\section{Notes}

Note 1. In terms of availability of natural resources, this planet has already exceeded its upper limit of the environmental carrying capacity. When this carrying capacity exceeds, there is an irreversible damage on the ecosystem. The overuse of land and depletion of land resources are the best examples to show the consequence of exceeded carrying capacity (see Pimentel, 1998 for details).

Note 2. Global estimates of tropical deforestation range from $69,000 \mathrm{~km}$ in 1980 to $10000-165000 \mathrm{~km}$. in the late 1980s (see David \& Tucker, 1997; for details also see Tucker \& Richard 'Global Disforestation in the Nineteenth Century World Economy’, 1983; Durham \& Williams, Prog Human Geography 13, [1989]).

Note 3. Thomas Robert Malthus is perhaps the first theoretician who propounded demographic theory with a pessimism showing that population increase will supersede food supply and resources which create problems for human survival [see Malthus, 1798]. 
Note 4. During the 1930s, the number of population was lowered and the reason was the decline in fertility, and the higher rate of mortality due to a number of reasons.

Note 5. A union is the lowest unit of local government organization in Bangladesh. It usually comprises of 6-15 villages and is governed by one chairman and nine members directly elected by the villagers.

Note 6. Physiographically, Rajshahi District is divided into three broad divisions: (a) the Barind Region, (b) the newly laid alluvial deposits along the bank of Padma and (c) the beel or marshy area (see Karim, 1990 for details).

Note 7. I have taken a few sample families from different class of peasants to represent their groups. In future, this will further be updated by interviewing each family to know specifically their everyday food consumption patterns.

\section{Copyrights}

Copyright for this article is retained by the author(s), with first publication rights granted to the journal.

This is an open-access article distributed under the terms and conditions of the Creative Commons Attribution license (http://creativecommons.org/licenses/by/3.0/). 